\title{
HMGA2/ALDH2 Fusion Gene
}

National Cancer Institute

\section{Source}

National Cancer Institute. HMGA2/ALDH2 Fusion Gene. NCI Thesaurus. Code C99428.

A fusion gene that results from paracentric inversion of chromosome 12 which juxtaposes the first 3 exons of the HGMA2 gene with exon 13 and part of the $3^{\prime}$ untranslated region of the ALDH2 gene. This fusion is associated with benign uterine leiomyoma. 